\title{
Influence of fly ash and sewage sludge application on wheat biomass production, nutrients availability, and soil properties
}

\author{
Christos Tsadilas • Vasilios Samaras • E. Evangelou • Sabry M. Shaheen
}

Received: 25 June 2014/Revised: 28 July 2014/Accepted: 2 August 2014/Published online: 26 September 2014

(C) The Author(s) 2014. This article is published with open access at Springerlink.com

\begin{abstract}
The influence of fly ash (FA) applied alone and/or with sewage sludge (SS) on wheat (Triticum vulgare) grain yield, biomass production and soil properties was studied in a field experiment. The results showed that both FA and SS significantly increased grain yield and plant biomass. FA applied alone increased significantly soil $\mathrm{pH}$ and EC while FA applied together with SS did not significantly affect them compared to mono FA treatment. Soil pH and EC values increased with time in FA and FA-SS treatments. SS increased soil organic matter and total N content and SS applied together with FA increased also available soil B. From the plant nutrients tested only tissue $\mathrm{N}$ concentration was increased significantly in all treatments compared to control. Copper, $\mathrm{Zn}, \mathrm{Mn}, \mathrm{Ni}$, and $\mathrm{Pb}$ at both available and total concentrations are significantly affected.
\end{abstract}

Keywords Fly ash $\cdot$ Sewage sludge $\cdot$ By-product of coal combustion $\cdot$ Wheat biomass product $\cdot$ Soil property

\section{Introduction}

Fly ash (FA), the by-product of coal combustion for energy production is a major environmental problem worldwide. FA management mainly includes its use for cement production, road-base construction, mine reclamation, mineral wool production, recovery of metals, and as aggregate substitute material. Recently FA has gained attention as a potential resource in terrestrial carbon sequestration. The incorporation of FA may also improve physical, chemical, and biological properties and thus benefit agricultural production (Ukwattage et al. 2013). Sewage sludge (SS) from the other hand, a by-product of the sewage effluents treatment, constitutes also a serious environmental problem requiring a safe and economical disposal. Due to its

C. Tsadilas $(\bowtie) \cdot$ V. Samaras $\cdot$ E. Evangelou National Agricultural Research Foundation, Institute of Soil Mapping and Classification, Larissa, Greece

e-mail: tsadilas@lar.forthnet.gr

S. M. Shaheen

Faculty of Agriculture, University of Kafrelsheikh,

Kafr El-Sheikh, Egypt composition and properties, SS may be beneficially used in agriculture as substitute of fertilizers or soil amendment. Europe, USA, and Asian countries already use SS in agriculture by taking advantages of its useful characteristics for soils and plants (Smith 1996). It was found that coapplication of FA and SS may enhance the beneficial effects from the soil application of these two by-products. However, FA and SS as inputs may have many benefits for agriculture like facing of nutrient deficiencies, while these by-products contain a number of toxic substances like toxic heavy metals and organic pollutants. Therefore a proper attention should be paid on the impacts of the use of these materials on soil health, crop quality and heavy metal toxicity and leaching. Greece is a country that produces large amounts of FA since the main energy source of the country comes from coal combustion. From the other hand SS disposal in Greece is still a serious problem since 30 years after the adoption of the rules for the agricultural use of SS from the EU and Greece with the Directive $86 / 278$, in essence its use in agriculture has not yet started. Therefore the management of both by-products, i.e., FA and SS, is of significant importance for Greece. Research work showed that both by-products FA and SS may be used 
Table 1 Selected properties of the soil, FA and SS used in the study

\begin{tabular}{llll}
\hline Properties* & Soil & FA & SS \\
\hline EC $(\mu \mathrm{S} / \mathrm{cm})$ & 129.5 & 5,480 & 3,240 \\
$\mathrm{pH}($ water $1: 1)$ & 5.25 & 12.2 & 6.02 \\
$\mathrm{OM}(\mathrm{g} / 100 \mathrm{~g})$ & 1.61 & .d. & 27.5 \\
$\mathrm{CEC}(\mathrm{cmol}(+) / \mathrm{kg})$ & 23.4 & 7.7 & 78.3 \\
Olsen-P $(\mathrm{mg} / \mathrm{kg})$ & 18.25 & - & - \\
Exch K $(\mathrm{cmol}(+) / \mathrm{kg})$ & 0.36 & - & - \\
$\mathrm{DTPA}$ extractable metals $(\mathrm{mg} / \mathrm{kg})$ & & \\
$-\mathrm{Cu}$ & 1.5 & - & - \\
$-\mathrm{Mn}$ & 20.2 & - & - \\
$-\mathrm{Zn}$ & 1.8 & - & - \\
$-\mathrm{Pb}$ & 0.7 & - & - \\
$-\mathrm{Ni}$ & 4.7 & - & - \\
$\mathrm{Total} \mathrm{metal} \mathrm{content}(\mathrm{mg} / \mathrm{kg})$ & & & - \\
$-\mathrm{Cu}$ & 25 & - & - \\
$-\mathrm{Mn}$ & 620 & 263 & 298 \\
$-\mathrm{Zn}$ & 67 & - & - \\
$-\mathrm{Pb}$ & 28 & 102 & 232 \\
$-\mathrm{Ni}$ & 78 & - & - \\
\hline
\end{tabular}

* EC Electrical conductivity, $O M$ organic matter, CEC cation exchange capacity, Exch $K$ exchangeable $\mathrm{K}$

in a beneficial and sustainable way facing thus serious environmental problems (Samaras et al. 2008; Tsadilas et al. 2009). The purpose of the present study was to investigate the possibility to use FA and SS in wheat crop separately or together and its influence on grain yield and soil properties including essential nutrients content as well as toxic heavy metals accumulation.

\section{Materials and methods}

\subsection{Field experimentation}

A field experiment was conducted in an area of Karditsa prefecture, western Greece, with durum wheat (Triticum aestivum) grown on a soil classified as Typic Haploxeralf with $25 \%$ clay, $30 \%$ silt and $45 \%$ sand. FA used was collected from a lignite-fired electric power plant located in Northern Greece which aged before its use for 3 months by maintaining in open air and leaching periodically with deionized water. FA was strongly alkaline with a $\mathrm{pH}$ 12.2. SS was collected from the wastewater treatment plant of the city of Tirnavos, located near to Larissa, central Greece. The basic characteristics of the soil and the amendments used are shown in Table 1. The experimental design was complete randomized blocks with the following treatments: control $(\mathrm{C})$, included only soil without inorganic fertilizer and soil amendments; Inorganic
Fertilization (IF), included fertilization with 12 units of $\mathrm{N}$ and 6 units of $\mathrm{P}_{2} \mathrm{O}_{5}$; FA plus inorganic fertilizer (T1-IF), included 5.56 ton/ha FA and the inorganic fertilizers referred above for IF treatment; FA plus inorganic fertilizer (T2-IF), included 11.25 ton/ha FA plus the same amount of fertilizer referred for the treatment T1-IF; FA plus SS (T1SS1), included 5.56 ton/ha FA plus 6.3 ton/ha dry SS; FA plus SS (T1-SS2) included 5.56 ton/ha FA plus 12.6 ton/ha dry SS. Each treatment was replicated four times. The dimensions of the plots were $4 \mathrm{~m} \times 4 \mathrm{~m}$. The fertilizer was composite in the form of $20-10-0$ and it was incorporated into the soil in a depth $20 \mathrm{~cm}$ for 2 days before sowing. FA and SS were incorporated into the soil 45 days before wheat sowing.

\subsection{Soil, plant, FA and SS samplings and analyses}

In November before sowing as well as at the end of March and May next year, soil samplings were conducted from a depth $0-20 \mathrm{~cm}$. The samples were air dried, crushed and sieved with a $2 \mathrm{~mm}$ sieve and analyzed for the properties referred below. At the time of the third soil sampling, plant sampling was also conducted including the above ground part of the plants. The plants were dried at $60{ }^{\circ} \mathrm{C}$, ground and analyzed for the basic nutrients according to Mills and Jones (1996). Wheat harvesting was done at the end of June and the grains were separated by the plants by handle and weighted for calculating the grain yield. Soil properties i.e., $\mathrm{pH}$ and electrical conductivity in a suspension 1:1 water:soil, cation exchange capacity by sodium acetate method, exchangeable $\mathrm{K}$ and $\mathrm{Mg}$ with the ammonium acetate method, organic matter with wet oxidation procedure with the potassium dichromate method, available $\mathrm{P}$ with the sodium bicarbonate method, total $\mathrm{N}$ with the Kjeldahl method, available B with the hot calcium chloride extraction method, available metals with the DTPA method, and total heavy metals were determined according to the procedures referred by Page et al. (1982). FA and SS were analyzed by the same methods used for soils.

\section{Results and discussions}
3.1 Influence of FA and SS on grain yield and plant nutrient uptake

Application of both FA and SS alone or together increased grain yield significantly compared to $\mathrm{C}$ in a similar way to inorganic fertilizers, although co-application of FA and SS tended to increase the yield more than the other treatments (Fig. 1). It means that the amendments used may replace inorganic fertilizers without reducing wheat yield. The influence of the amendments and fertilizer used was more 


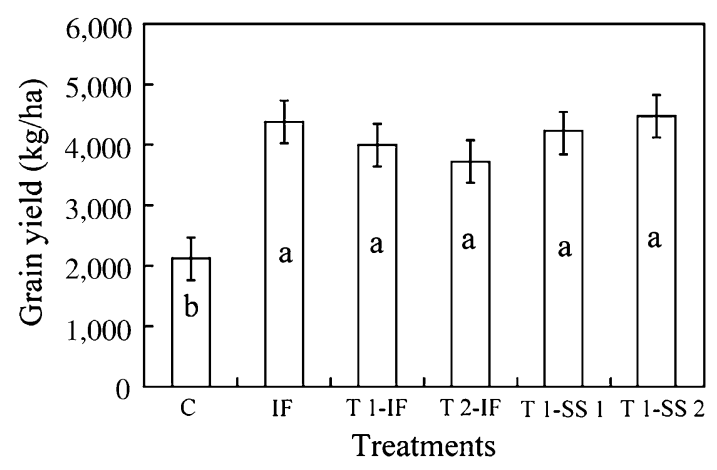

Fig. 1 Influence of the treatments applied on the grain yield of wheat. Numbers in the columns with different letters differ significantly according to the LSD test at the probability level $p<0.05$

complicated. In this case co-application of FA and SS at the higher rate without inorganic fertilizers (T1-SS2) had stronger influence on grain yield, increased it from 5.85 in the $\mathrm{C}$ ton/ha to 13.13 ton/ha. Inorganic fertilization alone without FA and SS increased biomass but at lower level compared to the treatments contained amendments. Regarding the rates applied, it seems that 5.5 ton/ha FA and 12 ton/ha SS are the most effective for biomass yield. Similar results of the influence of FA application on wheat grain yield were reported by Garg et al. (2005) and for rice grain yield (Mittra et al. 2005).

Plant uptake of the basic nutrients was not significantly affected except $\mathrm{N}$ (data not shown). The higher $\mathrm{N}$ concentration (1.61\%) was recorded in the treatment T1-SS2 (5.56 ton/ha FA plus 12.6 ton/ha dry SS). All the rest treatments had significantly lower $\mathrm{N}$ concentration in wheat tissues. It is remarkable that in all the treatments $\mathrm{N}$ concentration was lower than that considered as sufficiency range (1.75\%, Mills and Jones 1996). Phosphorus in all cases remained above the threshold of sufficiency range $(0.30 \%)$ ranged between $0.41 \%$ and $0.46 \%)$. Potassium ranged between $0.90 \%$ and $1.21 \%$ being higher in the treatment T1-SS2 and T1-SS1 compared to all the others but still lower than the sufficiency threshold $(2.50 \%)$. Magnesium concentration ranged between $0.076 \%$ and $0.086 \%$ being also quite below the sufficiency range of $0.15 \%$. Boron however, although it was not significantly affected by the treatments applied, was kept above the sufficiency rage of $5 \mathrm{~B} \mathrm{mg} / \mathrm{kg}$ (Mills and Jones 1996).

\subsection{Influence of FA and SS on soil properties}

FA and SS significantly influenced most of the soil properties studied (Table 2). Soil pH tended to decrease due to inorganic fertilizer application but the decrease was not significant. In all the rest treatments $\mathrm{pH}$ increased from 5.95 in the control to 7.52 in the treatment T2-IF and 7.15-7.52 in the treatments including the lower FA rate. It
Table 2 Influence of the treatments applied on soil properties

\begin{tabular}{lllllll}
\hline Property* & \multicolumn{5}{l}{ Treatments } \\
\cline { 2 - 7 } & Control & IF** & T1-IF & T2-IF & T1-SS1 & T1-SS2 \\
\hline $\mathrm{pH}$ & $5.95 \mathrm{c}$ & $5.67 \mathrm{c}$ & $7.15 \mathrm{a}$ & $7.52 \mathrm{a}$ & $7.22 \mathrm{a}$ & $7.25 \mathrm{a}$ \\
$\mathrm{EC}$ & $127 \mathrm{~b}$ & $192 \mathrm{~b}$ & $312 \mathrm{a}$ & $315 \mathrm{a}$ & $341 \mathrm{a}$ & $367 \mathrm{a}$ \\
$\mathrm{OM}$ & $1.80 \mathrm{~b}$ & $2.05 \mathrm{~b}$ & $2.17 \mathrm{~b}$ & $1.78 \mathrm{~b}$ & $3.30 \mathrm{a}$ & $3.15 \mathrm{a}$ \\
$\mathrm{N}_{\text {total }}$ & $0.101 \mathrm{c}$ & $0.122 \mathrm{bc}$ & $0.107 \mathrm{c}$ & $0.112 \mathrm{c}$ & $0.157 \mathrm{ab}$ & $0.162 \mathrm{a}$ \\
$\mathrm{P}_{\text {Olsen }}$ & $18.2 \mathrm{~b}$ & $40.0 \mathrm{a}$ & $48.5 \mathrm{a}$ & $34.2 \mathrm{ab}$ & $47.7 \mathrm{a}$ & $51.7 \mathrm{a}$ \\
$\mathrm{K}_{\text {exch }}$ & $0.37 \mathrm{a}$ & $0.48 \mathrm{a}$ & $0.47 \mathrm{a}$ & $0.45 \mathrm{a}$ & $0.53 \mathrm{a}$ & $0.45 \mathrm{a}$ \\
$\mathrm{Mg}_{\text {exch }}$ & $3.34 \mathrm{ab}$ & $3.07 \mathrm{~b}$ & $3.17 \mathrm{~b}$ & $3.35 \mathrm{ab}$ & $3.45 \mathrm{ab}$ & $3.72 \mathrm{a}$ \\
$\mathrm{HwsB}$ & $0.77 \mathrm{c}$ & $0.80 \mathrm{c}$ & $1.25 \mathrm{bc}$ & $1.47 \mathrm{ab}$ & $1.72 \mathrm{a}$ & $1.70 \mathrm{a}$ \\
\hline
\end{tabular}

$E C$ electrical conductivity in $\mu$ mhos/cm, $O M$ organic matter in $\mathrm{g} / 100 \mathrm{~g}$ soil, $N_{\text {total }}$ Total $\mathrm{N}$ in g/100 g soil, $K_{\text {exch }}$ exchangeable K in cmol(+)/kg soil, $M g_{\text {exch }}$ exchangeable $\mathrm{Mg}$ in $\mathrm{cmol}(+) / \mathrm{kg}$ soil, $H w s B$ hot water soluble boron in $\mathrm{mg} / \mathrm{kg}$ soil

* pH: 1:1 water:soil ratio

** Numbers in the same column followed by different letters differ significantly according to the LSD test at the probability level $p<0.05$

seems that in the treatments including SS the $\mathrm{pH}$ increase was lower than in the treatments with no SS probably due to the buffering capacity of the organic matter contained in SS. As was expected, electrical conductivity was significantly increased in all the treatments included FA and SS due to their high soluble salts content. However, this increase was not at harmful level for salt tolerant crops like wheat (Katerji et al. 1999). Similar results on pH soil and electrical conductivity were obtained after co-application of FA and SS by (Masto et al. 2012).

Organic matter content significantly increased in the treatments contained SS (T1-SS1, T1-SS2) from $1.80 \%$ in the $\mathrm{C}$ up to $3.15 \%$ and 3.30 in the treatment T1-SS2 and T1SS1, respectively. This contribution of SS is considered important especially in Mediterranean environments where soils are poor in organic matter. Similar results were found for the influence of SS on soil organic matter content by several others (Shaheen and Tsadilas 2013). A similar trend to organic matter content was recorded also for total $\mathrm{N}$ content since they are closely related. From $0.101 \%$ in the C it was increased to $0.162 \%$ in the treatment T1-SS2. Another noteworthy effect of the co-application of FA and SS was found on soil P. It is noticed that phosphate is almost exclusively obtained from phosphate rock, which is not a renewable source and it is expected to be depleted in about 100 years (Smil 2000). Consequently, to avoid P shortage, any source of $\mathrm{P}$ should be utilized. One of these sources seems to be SS (Guedes et al. 2014). In the present study it was found that application of SS increased available soil P from $18.2 \mathrm{mg} / \mathrm{kg}$ soil up to about 51.7, i.e., three times more than in $\mathrm{C}$ (Table 2). In addition, regression analysis showed that available soil was significantly correlated with grain 


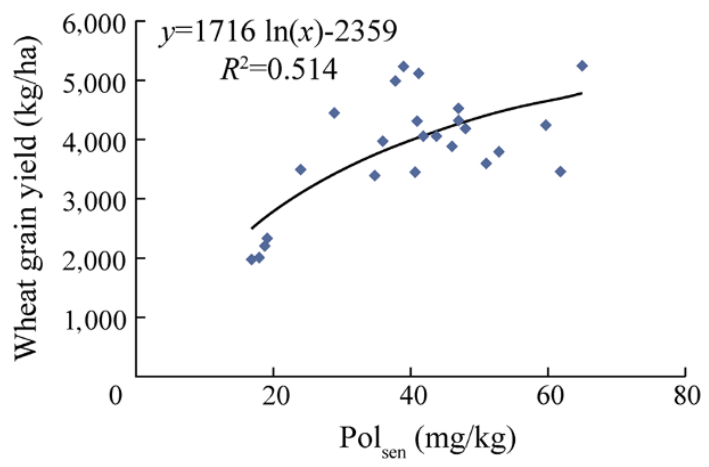

Fig. 2 Relationship between available soil $\mathrm{P}$ and wheat yield

Table 3 Influence of FA and SS application on soil heavy metal content

\begin{tabular}{cclllll}
\hline Metal* & \multicolumn{5}{l}{ Treatments } \\
\cline { 2 - 7 } & Control & IF & T1-IF & T2-IF & T1-SS1 & T1-SS2 \\
\hline DTPA extractable & & & & & \\
$\mathrm{Cu}$ & $1.72 \mathrm{abc}$ & $1.65 \mathrm{bc}$ & $1.4 \mathrm{c}$ & $1.3 \mathrm{c}$ & $2.0 \mathrm{ab}$ & $2.17 \mathrm{a}$ \\
$\mathrm{Mn}$ & $18.9 \mathrm{~b}$ & $25.2 \mathrm{a}$ & $7.8 \mathrm{c}$ & $6.5 \mathrm{a}$ & $6.9 \mathrm{a}$ & $6.5 \mathrm{a}$ \\
$\mathrm{Zn}$ & $1.87 \mathrm{c}$ & $3.95 \mathrm{c}$ & $2.37 \mathrm{c}$ & $2.67 \mathrm{c}$ & $9.1 \mathrm{~b}$ & $14 \mathrm{a}$ \\
$\mathrm{Pb}$ & $0.72 \mathrm{bc}$ & $0.7 \mathrm{c}$ & $0.5 \mathrm{c}$ & $0.47 \mathrm{c}$ & $1.20 \mathrm{ab}$ & $1.35 \mathrm{a}$ \\
$\mathrm{Ni}$ & $4.67 \mathrm{a}$ & $5.10 \mathrm{a}$ & $2.55 \mathrm{~b}$ & $1.97 \mathrm{c}$ & $1.97 \mathrm{c}$ & $2.0 \mathrm{c}$ \\
$\mathrm{Total}$ content & & & & & \\
$\mathrm{Cu}$ & $25 \mathrm{~b}$ & $25.2 \mathrm{~b}$ & $26 \mathrm{~b}$ & $25.2 \mathrm{~b}$ & $32 \mathrm{a}$ & $32.2 \mathrm{a}$ \\
$\mathrm{Mn}$ & $630 \mathrm{a}$ & $628 \mathrm{a}$ & $663 \mathrm{a}$ & $621 \mathrm{a}$ & $618 \mathrm{a}$ & $650 \mathrm{a}$ \\
$\mathrm{Zn}$ & $65.2 \mathrm{~b}$ & $67.5 \mathrm{~b}$ & $66.2 \mathrm{a}$ & $67.7 \mathrm{a}$ & $106 \mathrm{a}$ & $108 \mathrm{a}$ \\
$\mathrm{Pb}$ & $21.7 \mathrm{~b}$ & $22 \mathrm{~b}$ & $21.5 \mathrm{~b}$ & $24.2 \mathrm{~b}$ & $31.2 \mathrm{a}$ & $30.7 \mathrm{a}$ \\
$\mathrm{Ni}$ & $76.7 \mathrm{a}$ & $76.5 \mathrm{a}$ & $77.7 \mathrm{a}$ & $80.2 \mathrm{a}$ & $76.7 \mathrm{a}$ & $76.2 \mathrm{a}$ \\
\hline
\end{tabular}

* Numbers in the same lines followed by different letters differ significantly according to the LSD test at the probability level $p<0.05$

yield as it is shown in Fig. 2. Similar results on the influence of SS on the available soil $\mathrm{P}$ were reported by Shaheen et al. (2012). No any influence was recorded by FA and SS application available $\mathrm{K}$ and $\mathrm{Mg}$ (Table 2).

FA alone or together with SS increased significantly available soil B. In the treatments without SS, FA increased gradually soil B from $0.77 \mathrm{mg} / \mathrm{kg}$ in the $\mathrm{C}$ to $1.25 \mathrm{mg} / \mathrm{kg}$ in the treatment T1-IF and $1.47 \mathrm{mg} / \mathrm{kg}$ in the treatment T2-IF. When FA was co-applied with SS, the increase was higher i.e., up to $1.72 \mathrm{mg} / \mathrm{kg}$ due to the additional contribution to B from SS. However, plant B uptake was not significantly influenced probably due to the adequate available B content of the original soil.

\subsection{Influence of FA and SS on soil heavy metal content}

FA and SS influence on soil heavy metal content is presented in Table 3. Regarding the available forms of heavy
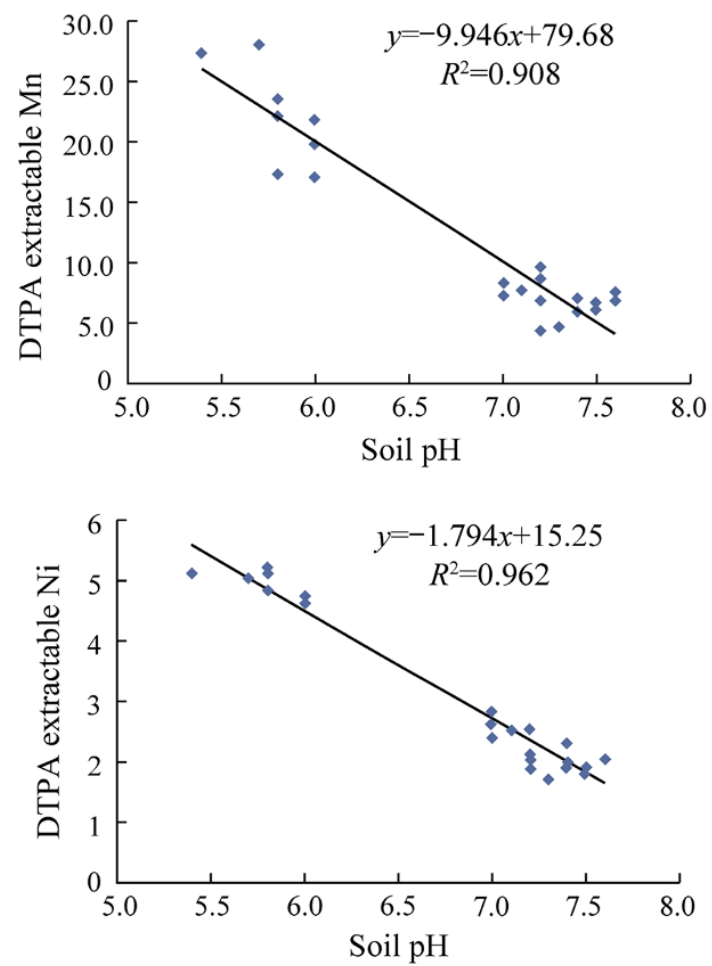

Fig. 3 Relationship between soil pH and DTPA extractable Mn and $\mathrm{Ni}$
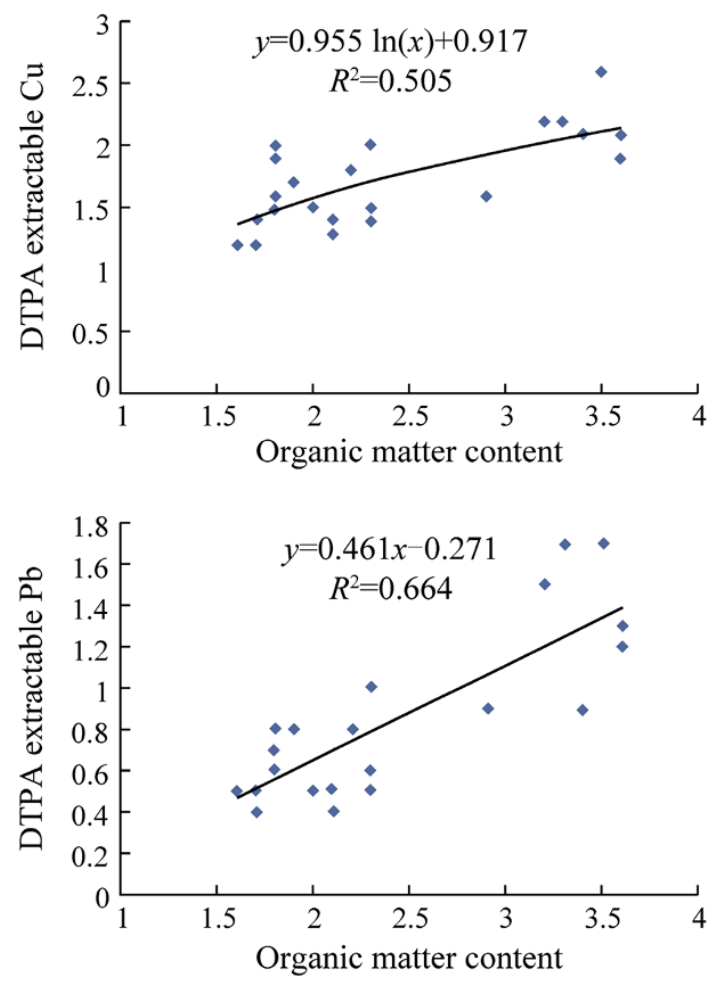

Fig. 4 Relationship between organic matter content (\%) and DTPA extractable $\mathrm{Cu}$ and $\mathrm{Pb}\left(\mathrm{mg} \mathrm{kg}^{-1}\right.$ soil ) 

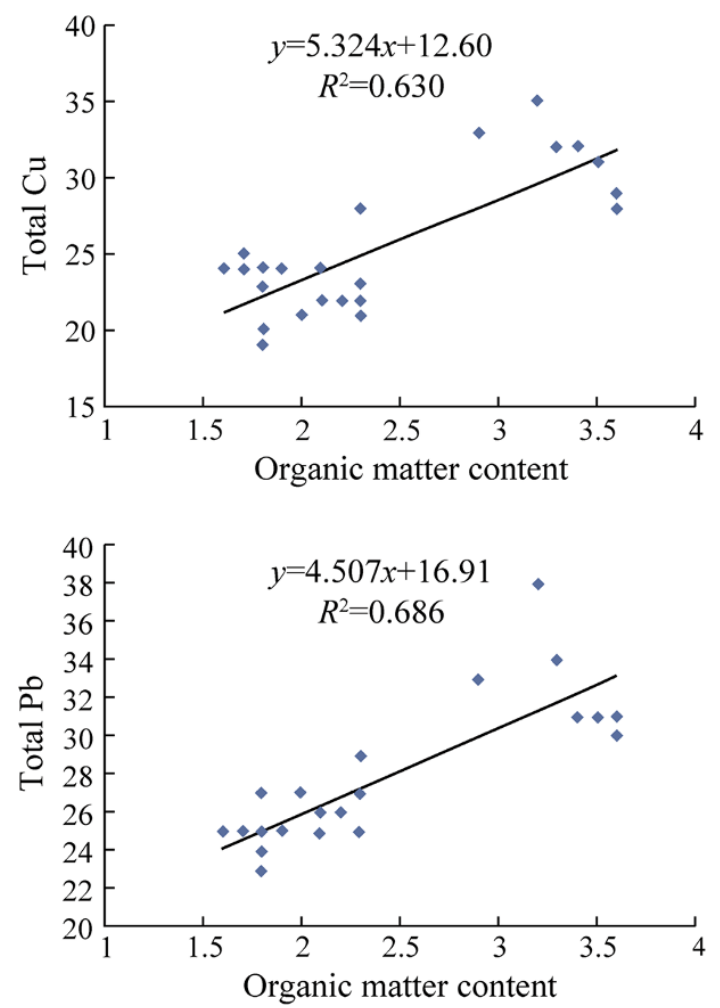

Fig. 5 Relationship between organic matter content (\%) and total $\mathrm{Cu}$ and total content $\mathrm{Pb}\left(\mathrm{mg} \mathrm{kg}^{-1}\right.$ soil)

metals it is obvious that $\mathrm{Mn}$ and $\mathrm{Ni}$ were strongly influenced due to the application of the amendments. This is because of the strong negative correlation between these two forms and soil pH (Fig. 3).

$\mathrm{Cu}_{\text {DTPA }}$ tended to decrease in the treatments T1-IF, T2IF, probably due to $\mathrm{pH}$ increase, but increased in the treatments T1-SS1, and T1-SS2, probably due to the organic matter increase after SS application. Organic matter content and $\mathrm{Cu}_{\text {DTPA }}$ were positively correlated (Fig. 4). $\mathrm{Pb}_{\text {DTPA }}$ increased only in the treatments contained SS (T1-SS1, T1-SS2) which means that this influence is due to the relatively high $\mathrm{Pb}$ content of SS (Table 1) or to the positive correlation of that with organic matter content.

The influence of the amendments used on the total metal content is shown in Table 3. Total Mn content was not significantly affected by the addition of both amendments applied. Zinc significantly increased in the treatments included both FA and SS while in the case of their coapplication the increase was higher (T1-SS1, T1-SS2) compared to those they were applied separately (T1-IF, T2IF), which means that both amendments added Zn. Copper and $\mathrm{Pb}$ however, increased only in the treatments included SS (T1-SS1, T1-SS2). This means that these two metals are correlated with the organic matter content of SS, as it is clearly shown in the Fig. 5. However, it is remarkable that $\mathrm{Cu}$ and $\mathrm{Pb}$ increased only in treatments included SS addition (T1-SS1 and T1-SS2), which means that this influence is due to the positive correlation of total $\mathrm{Cu}$ and $\mathrm{Pb}$ contents with the organic matter content (Fig. 5). The relationship between $\mathrm{Cu}$ and $\mathrm{Pb}$ as well as between them and organic matter was mentioned by several others. For example Sipkova et al. (2014) reported for ten soils from Czech Republic that between these two elements there were a coefficient of determination $R^{2}=0.81$ and about $20 \%$ of these elements were bound to organic matter. In our study the respective coefficient between $\mathrm{Cu}$ and $\mathrm{Pb}$ was $R^{2}=0.863$.

\section{Conclusions}

From the results of this study it is concluded that FA applied alone or/and together with SS affects positively wheat grain and biomass yield. Soil $\mathrm{pH}$ increases as well as electrical conductivity but at levels no harmful to salt tolerant crops. In addition, significant increase is obtained in available soil $\mathrm{P}$ and $\mathrm{B}$. Zinc and $\mathrm{Pb}$ concentrations at both available and total form increase, available $\mathrm{Mn}$ and $\mathrm{Ni}$ available forms decrease. It seems therefore that if we use FA and SS in the proper amounts, so that to keep the toxic heavy metal at acceptable levels, we could get benefits from their application to soil.

Open Access This article is distributed under the terms of the Creative Commons Attribution License which permits any use, distribution, and reproduction in any medium, provided the original author(s) and the source are credited.

\section{References}

Garg RN, Pathak H, Das DK, Tomar RK (2005) Use of flyash and biogas slurry for improving wheat yield and physical properties of soil. Environ Monit Assess 107:1-9

Guedes P, Couto N, Ottosen LM, Ribeiro AB (2014) Phosphorus recovery from sewage sludge ash through an electrodialytic process. Waste Manag 34:886-892

Katerrji N, van Hoom JW, Hamdy A, Mastrorilli M (1999) Salt tolerance classification of crops according soil salinity and water stress day index. Agric Water Manag 43:99-109

Masto RE, Sumar KK, Sengupla T, Rout LC, Selvi VA, George J, Sinha AK (2012) Evaluation of co-application of fly ash and sewage sludge on soil biological and biochemical quality. Environ Technol 33(8):897-905

Mills HA, Jones JB (1996) Plant analysis handbook II. A practical sampling, preparation, analysis, and interpretation manual. Micro-Macro Publishing Inc., Athens, p 422

Mittra BN, Kamakar S, Swain DK, Ghosh BC (2005) Fly ash-a potential source of soil amendment and a component of integrated plant nutrient supply system. Fuel 84:1447-1451

Page AL, Miller RH, Keeney (eds) (1982) Methods of soil analysis, Part 2, chemical and microbiological properties, 2nd edn. ASA, SSSA, Madison, p 1159 
Samaras V, Tsadilas CD, Stamatiadis S (2008) Effects of repeated application of municipal sewage sludge in a cotton field: effects on soil fertility, crop yield, and nitrate leaching. Agron J 100:477-483

Shaheen S, Tsadilas C (2013) Utilization of biosolids in production of bioenergy crops I: impact of application rate on canola biomass, soil properties, and nutrient availability. Commun Soil Sci Plant Anal 44:243-258

Shaheen SM, Shams MS, Elbehiry FA, Ibrahim SM (2012) Influence of stabilized biosolids application on availability of phosphorus, coper, and zinc. Appl Environ Soil Sci. http://dx.doi.org/10. $1155 / 2012 / 817158$

Sipkova A, Szakova J, Thustos P (2014) Affinity of selected elements to individual fractions of soil organic matter. Water Air Soil Pollut 225:1-11
Smil V (2000) Phosphorus in the environment: natural flows and human interferences. Annu Rev Energy Environ 25:53-88

Smith SR (1996) Agricultural recycling of sewage sludge and the environment. CAB International, Wallingford, p 382

Tsadilas C, Shaheen S, Samaras V, Gizas D, Hu Z (2009) Influence of fly ash application on copper and zinc sorption by acidic soil amended with sewage sludge. Commun Soil Sci Plant Anal 40(1-6):273-284

Ukwattage NL, Ranjith PG, Bouazza M (2013) The use of coal fly ash as a soil amendment in agricultural lands (with comments on its potential to improve food security and sequester carbon. Fuel 109:400-408 